\title{
Breaking the mold of disciplinary area studies
}

Premesh Lalu

At the outset of an edited volume on Intellectuals and African Development, the question is posed about what went wrong. ${ }^{1}$ The call for self-reflection perhaps anticipates a further question-about how to account for the effects of area studies on scholarship in Africa in the era of independence and development. Much of this reflection has of course been occasioned by the work of scholars initially educated in African universities but later located in the American academy. Many have argued saliently about the perils of proceeding without significant and substantial overhauls to prevailing orthodoxies derived from area studies as they were constituted in the American academy. Perhaps one way to think about the anxieties produced by area studies for scholars of African studies relates to the manner in which the consolidation of institutions of higher learning in the West after the Second World War was buoyed by knowledge from elsewhere. Dipesh Chakrabarty, in his musings on American area studies in South Asia, identifies the asymmetry between knowledge and institution as a hangover of an older connection between liberal education and empire. ${ }^{2} \mathrm{He}$ suggests that what made these Eurocentric assumptions invisible was in part the fact that area studies were still a matter of studying cultures that were foreign. The question is ultimately, what critical attitude is to be harnessed from within this scene of estrangement to articulate another perspective on the worldliness of knowledge that the late Edward Said once encouraged. Thinking about the inheritance of area studies after Said's Orientalism or Valentine Mudimbe's Invention of Africa is what now pressures a generation toward recharging the effective history of postcolonial criticism.

If area studies produced anxiety about being in the world among scholars writing on Africa, then we might add that its consequences are considerably multiplied in the context of Africa. Rather than simply function as a receptacle of knowledge produced in the US academy, the promise of trickle-down modernity is cause for reflection on how we might proceed, not at the expense of the US academy, but in relation to it, and beyond its preordained scripts of area studies formed at the height of the Cold War. This might require a reorientation, if not an overhauling of that which is called area studies in the United States, if not a breaking out of its disciplinary mold and political function. 
In what follows, I wish to return to the blind spots and oversights of area studies, in part to identify more carefully the anxieties encountered in the American academy about the study of Africa, and more precisely to ask what it might mean to imagine area studies beyond the prescriptions of the justificatory structure of the Cold War. How did area studies come to matter at the institutional site of the university in Africa, if at all? What have been its legacies, and what have been its shortcomings for African scholars and institutions? Rather than simply affirm the reorientation of area studies, I want to call attention to what it is that area studies may have foreclosed, rendering it prohibitive, rather than generative, for the academy located outside of the West-what, in its blind spots and oversights, may have augmented the question "what went wrong" and more pertinently, "what is the way out?" This is not another effort at trumping area studies in the United States for their ideological attachments, but an effort to ask what it might mean to reorient them, from elsewhere, toward institutional forms, aesthetic education, and questions that pressure thought at the limit of the geopolitics in which area studies were first conceived. How can area studies, in other words, change American attitudes, rather than affirming its racial presuppositions about the rest of the world? If the Cold War implications of area studies are less of a concern in what I offer, it is to the extent that African studies as a specific instance of area studies had made common course with the civil-rights movements in the United States, and opened the face of area studies to the anticolonial nationalist and independence struggles in Africa.3 That, however, is where the energies of area studies appear to have dissipated, at least as they made common cause with a nationalist moment in the constitution of independent African states.

The consequences of area studies in Africa are difficult to gauge in any definitive sense. Several scholars point to moments of great importance, as in the cohering of intellectuals in the Centre for African Studies, initiated by Kwame Nkrumah in Ghana in the wake of independence. 4 Others point to their relative absence in the formation of intellectual traditions as in southern Africa.5 Yet others point to their surreptitious effects in determining the questions and perspectives that define the study of Africa. 6 At the very least, these questions and perspectives were themselves efforts at grasping the constraints of Cold War narratives, charged with the desire for alternative visions of the world. This is possibly the implication of the division of labor that Thandika Mkandawire and Paul Zeleza call into question in their respective studies of area studies in the United States.

Beyond the criticism of the effects of area studies in the United States looms a larger question-of how we come to anticipate the form of disciplinary reason that area studies constituted for African knowledge projects and institutions. The 
question now comes to us forcefully, especially as the institutional mechanisms of higher education in Africa have become susceptible to a consultancy culture, which, according Mahmood Mamdani, truncates the academic structure toward serving the interests of development agencies.7 One possible reading of this drift toward a consultancy culture, beyond the lack of funding commitment by African states for higher education, or a capacious notion of neoliberalism, rests with the way African studies programs such as the Title VI grants in the United States generally bypassed institutional mechanisms in Africa. The consequence is that African universities were increasingly placed in competition with nongovernmental organizations (NGOs) for funding resources, rather than being viewed as equal partners in the knowledge project. Today, those NGOs have mostly displaced the institutional site of the university as an extension of American interests. Bypassing the traumatized university, area-studies programs now forget that their earlier attachments may have resulted in answering in part, what precisely went wrong.

As a form of disciplinary reason, area studies in the United States generally failed to attend to the question of building institutions of higher learning in Africa. By disciplinary reason, I mean specifically a knowledge project set against what is both knowable and still to be known. Disciplinary reason is free of risk, holding both subject and object in place by blocking the flow of desire. Such disciplinary alignments between Global North and Global South functioned to thwart the creativity required in the formation of durable institutions of knowledge in Africa. While the Rockefeller, Ford, Mellon, and other foundations required institutional development as a basis for making grants, most North American programs tended to bypass African institutions, pushing the latter increasingly toward securing greater access to much-needed resources through consultancies. If a longer genealogy of area studies is undertaken, we might find that its formation reaches beyond the Cold War into the age of empire, and the protocols established in the age of empire of knowing as a basis of governing.

Area studies arguably tended to see African institutions as a continuation of a modular form established in the West. The rise of schools in Ghana, Ibadan, Makerere, and Dares Salaam each had a direct connection to the metropolitan models of higher education. The rigid approach to the idea of the university inhibited experimentation with new forms of pedagogy and research. The onset of African independence was accompanied by a recharged confidence among newly formed states, resulting in a proliferation of higher education institutions across the continent. Several of these attended to the development priorities of newly independent states. Those that rose to prominence were integrally involved in a critique of the limits of independence in a political economy that proved resilient to the paradigms of African development. Area studies, it seems, remained aloof from this shift that defined institutional emergence in Africa. 
That was not all to which area studies appeared to be aloof. Neglect of an account of institutional formation meant that the possibilities of suturing links between an aesthetic realm beyond the confines of the university were deferred, with detrimental consequences for the project of building institutions of higher learning. At one level, this inhibited a self-styled postindependence university from drawing on aesthetic resources to break the hold of the instrumentality of colonial reason in the formation of the university in Africa. Area studies, with its geopolitical priorities, failed to appreciate the potential of an aesthetic realm to nurture a new concept of independence-one that exceeded the limits of scripts of development. A result of this unfortunate disconnect was that arts, music, film and theater education always lagged behind statist demands for a technologically overdetermined understanding of modernization. The flourish of literature, music, art, performance, and film in the wake of independence seemed to be completely obscured as interventions in the making of an African modernity or political subjectivity. Most were jettisoned to a life outside the university, where perhaps fortuitously, the artistic practices flourished. At the institutional site of the university in Africa, once-thriving attention to the creative disciplines in Ghana and Dakar in the 1960s, for example, seem gradually to have been displaced by the privileging of social sciences in area-studies programs in the 1980s. 8

This modality of area studies that defined relations between the academy of the United States and Africa resulted in a breakup of the epistemic duration that gave to African independence a poetics and temporality that enabled its intellectuals to set to work on unraveling the event of colonialism. Area studies carved up the epistemic field, perpetuated and compelled disciplinary reason at the expense of finding a concept of the humanities that would affect the emergence of institutions of higher learning in Africa, and perhaps cut short an opportunity to debate the priorities of Western liberalism. Rather than finding in Africa the potential for an antidisciplinary provocation that would give to the humanities its most sustainable resource, Africa was reduced to a case study, a research site, and more recently, a destination for humanitarian and development aid. Each, in turn, has replenished the disaster that awaits the epistemic revival of African scholarship, either by acting as a gatekeeper of what is acceptable disciplinary knowledge of Africa or by evacuating the space of deep conceptual thought and aesthetic education with an empirical imperative. If nationalism failed to come into its own because it was always seemingly belated in the story of the nation, area studies seem to have nailed that sentiment to the proverbial mast of knowledge and geopolitics by thwarting desire and underdeveloping aesthetic education.

But this script is already coming apart in the United States, where scholars today transgress disciplinary boundaries readily and freely, experiment endlessly, and shift directions effortlessly, while their African counterparts are 
pressured by demands for more case studies. Area studies for Africa functions less as a narrative of the Cold War than as a disciplinary prescription that binds scholars on the continent to the vicissitudes of an institutional apparatus stripped of a desire for the practice of freedom.

The study of Africa is cast in the mold of area studies in part because we come after the geopolitics that defined the Cold War, and in relation to which the project of knowledge and emancipation were attenuated. Any further deconstruction of what is already coming apart requires a process of learning to learn whether we are to preserve a healthy attitude toward knowledge produced in Africa. Such a perspective is now available in sections of the American academy following the significant cultural and political debates surrounding the discipline of comparative literature, itself a product of the Cold War program of area studies. 9 African studies in both the United States and Africa may need to take a leaf from the book, at least for learning to learn how to reorient its potential toward what Achille Mbembe recently called a planetary library.

African scholars, especially younger scholars, are clearly seeking new alliances with the academy in the United States. Many with degrees from American institutions are realizing the limits of an African studies devoid of a planetary sensibility. I will draw on three examples from the institution I know best, the Centre for Humanities Research (CHR) at the University of the Western Cape (UWC), where a new exchange across hemispheres may indeed be breaking out of the constraints and molds of an earlier instantiation of area studies. I offer these examples not to single out the CHR for special attention, but to disclose how new questions and energies of graduate students are beginning to redefine the study of Africa.

The first example relates to the increasing attention given to the problematic of what some scholars are calling global apartheid, and by which they mean to conceptualize a present that enables a broader genealogy of a politics of sovereign biopolitics that has race war as its unstated rationale. Here, the question of both old and new technologies that affect forms of subjection has become increasingly pertinent areas of inquiry. The second is reflected in the shift toward exploring developments in African American studies in the United States, particularly around jazz, Afro-futurism, and the technologies of race. Here, the work of scholars such as Fred Moten (In the Break) and Alexander Weheliye (Phonographies: Grooves in Sonic Afro-Modernity) are emerging as key interlocutors for a generation of scholars and artists. Texts by Moten and Weheliye are often read in relation to Achille Mbembe's On the Postcolony, Souleymane Bachir Diagne's African Art as Philosophy, Judith Butler's Precarious Life, and Gayatri Spivak's Aesthetic Education, each of which has inspired increasing research risks among younger scholars. The renewed effort to 
constitute the field of aesthetic education to counter the slide into a consultancy culture is important to note, not least because it is bringing scholars in the humanities into a more direct relation to emerging and ongoing artistic practices and thinking in the world. A third area that appears to be pressuring the older models of area studies relates to the way migrancy is being reconceptualized to the extent that it is offering fresh formulations of the question of political subjectivity. At a recent conference reflecting on twenty years since the publication of Citizen and Subject convened by Suren Pillay at the CHR at UWC, scholars such as Siba Grovogui, Nivideta Menon, Partha Chatterjee, Adelwahab al-Effendi Osman, Karuna Mantena, Mbongeseni Buthelezi, Steven Friedman, Lyn Ossome, Namhla Mashanda, Ari Sitas, and Brian Raftopolous engaged the question of political theory and philosophy as it refigured approaches to understanding a late colonial inheritance of governmentality and its consequences for thinking the present formation of political subjectivities in Africa. The examples here are indications of the inquiry unfolding more generally across the continent: they point to deepening philosophical attitudes and aesthetic interventions, resulting in new alignments between institutions and the state, and institutions and the public sphere.

In the aftermath of area studies, we may choose to adopt a posture of learning to learn from the interests of graduate students in Africa, precisely at a time when the instabilities of the modular form of American hegemony and its institutional mechanisms demand new perspectives. Perhaps a reorientation of the study of Africa under these conditions might invite consideration of institutional, aesthetic, and technological mediations in efforts to think of ways out of the predicament of the failures of development discourses. To this end, the possibilities of approaching Africa as more than a research site may call into being the desires and demands for the formation of new knowledge infrastructures in Africa. This is where desire calls for exceeding disciplinary reason. What better a way to proceed than by breaking out of the mold of area studies as it is currently given to us, while gesturing toward relinking the institutional sites of knowledge in Africa to a planetary library. 


\section{Notes}

1. Bjorn Beckman and Gbemisola Adeoti, eds., Intellectuals and African Development: Pretension and Resistance in African Politics (Dakar: CODESRIA, 2006).

2. Jackie Assayag and Veronique Benei, eds., At Home in Diaspora: South Asian Scholars and the West (Bloomington: Indiana University Press, 2003), 56.

3. This is not to deny the contests over African studies that filtered through the African Studies Association in the 1960s, and the ways in which a specifically identitarian politics functioned as an imprint on the institutional shape of African universities.

4. Jean Allman, "Kwame Nkrumah, African Studies and the Production of Knowledge in the Black Star of Africa," International Journal of African Historical Studies 46 (2013): 181-203.

5. Brian Raftopolous, "Zimbabwe Institute of Development Studies: The Early Context of Sam Moyo's Intellectual Development," Agrarian South Journal (forthcoming).

6. Paul Tiyambe Zeleza, ed., The Study of Africa, Vol. 1: Disciplinary and Interdisciplinary Encounters (Dakar: CODESRIA, 2006), and The Study of Africa, Vol. 2: Global and Transnational Engagements (Dakar: CODESRIA, 2007).

7. Mahmood Mamdani, Scholars in the Marketplace (Dakar: CODESRIA, 2007).

8. For a comparative example of the privileging of social science in area-studies programs, see Tim Mitchell, "The Middle East in the Past and Future of Social Science," UCIAS Series 3 (2003): 1-32.

9. Gayatri Spivak, Death of a Discipline (New York: Columbia University Press, 2003). 